\title{
Synthesis of herbertenediol and mastigophorenes A-D
}

\author{
A. Srikrishna and M. Srinivasa Rao \\ Department of Organic Chemistry, Indian Institute of Science \\ Bangalore 560012, India \\ E-mail: ask@orgachem.iisc.ernet.in
}

Dedicated to Professor S. Swaminathan

(received 24 Dec 04; accepted 27 Jan 05; published on the web 03 Feb 05)

\begin{abstract}
Formal total synthesis of $( \pm)$-herbertenediol and mastigophorenes A-D, starting from vanillin, has been described. A combination of alkylation, Wacker oxidation and intramolecular aldol condensation was employed for the generation of the cyclopentenone with two vicinal quaternary carbon atoms.
\end{abstract}

Keywords: Herbertanes, sesquiterpene synthesis, intramolecular aldol condensation, vicinal quaternary carbon atoms

\section{Introduction}

Liverworts from the genus Herbertus contain herbertane sesquiterpenoids which are considered as chemical markers of the genus. ${ }^{1}$ The herbertane group is a class of aromatic sesquiterpenes, containing sterically crowded 1-aryl-1,2,2-trimethylcyclopentane carbon framework incorporating two vicinal quaternary carbon atoms on a cyclopentane ring. The first member of this class of sesquiterpenes, herbertene 1, was isolated in 1981 by Matsuo and coworkers from the ethyl acetate extract of the liverwort Herberta adunca (Dicks.) S. Gray belonging to the family Herbertaceae. ${ }^{2}$

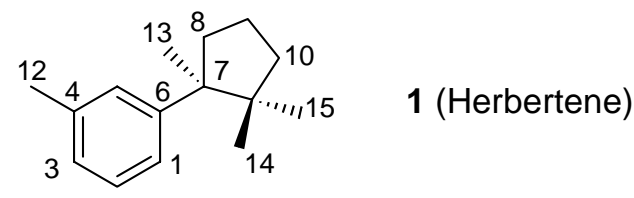

In 1982, research groups of Matsuo and Asakawa have reported isolation of three phenolic herbertanes, $\alpha$-herbertenol 2, $\alpha$-formylherbertenol 3 and $\beta$-herbertenol 4 along with herbertene 1 
and cuparene sesquiterpenes from the species $H$. aduncus, $H$. sakuraii and $H$. subdetatus. ${ }^{3}$ Isolation of two more herbertenoids herbertenediol $\mathbf{5}$ and herbertenolide $\mathbf{6}$ was reported in 1983 by Matsuo and coworkers. ${ }^{4}$ In 1988 and 1991 Asakawa and coworkers reported the isolation of the dimeric herbertanes, mastigophorenes A-D 7-10, dimers of herbertenediol 5, from the liverwort Mastigophora diclados (Mastigophoraceae). ${ }^{5}$ The mastigophorenes A-D 7-10 are presumably formed by one electron oxidative phenolic coupling of herbertenediol 5 . Subsequently, isolation of several herbertenoids 11-21 from various liverworts was reported. ${ }^{1,6}$ Structures of the herbertanes and mastigophorenes known so far are depicted in Chart 1.
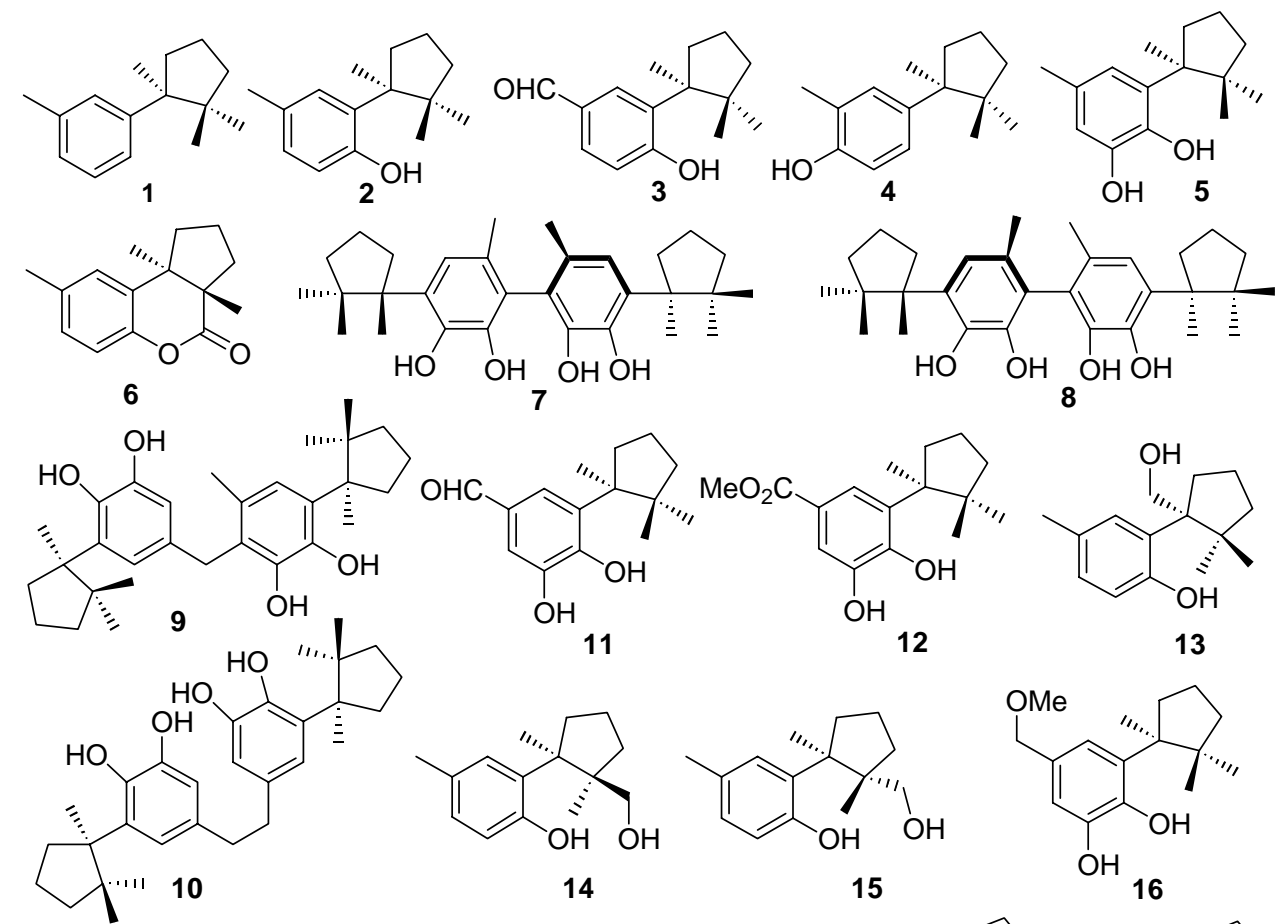

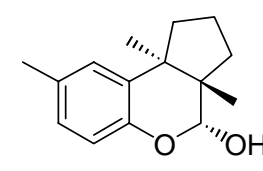

17

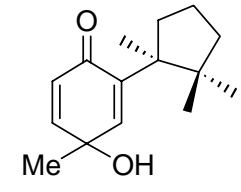

$18 \mathrm{a}, \mathrm{b}$

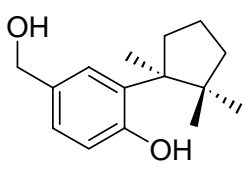

19<smiles>Cc1cc(O)cc([C@]2(C)CCCC2(C)C)c1</smiles>

20

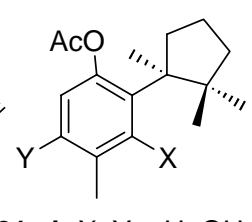

21a,b $X, Y=H, O H$

\section{Chart 1}

The herbertane sesquiterpenes, mainly the phenolic herbertanes have been shown to possess interesting biological properties such as growth inhibiting activity, antilipid peroxidation activity. ${ }^{3,4,6}$ The growth inhibiting activity of a few herbertenoids was tested on some plant pathogenic fungi. Some of the phenolic herbertanes were found to be strong inhibitors of the plant pathogenic fungi, Botrytis cinerea, Rhizoctonia solani and Pythium debaryanum. Mastigophorenes A-D 7-10 were found to exhibit intriguing neurotropic properties i.e. promote neuronal out growth and enhance choline acetyl transferase activity in the primary cultures of fetal rat cerebral hemisphere. 
Presence of an interesting carbon framework, sterically crowded 1-aryl-1,2,2trimethylcyclopentane, the difficulty associated with the construction of vicinal quaternary carbon atoms on a cyclopentane ring, and the novel biological properties associated with the phenolic herbertanes made the herbertenoids and mastigophorenes challenging synthetic targets. Even though, herbertanes were known since 1981, very little synthetic effort was reported in the literature on the synthesis of phenolic herbertanes prior to 1999. However during the past five years more than 25 publications appeared in the literature on the synthesis of herbertanes. ${ }^{7-9}$ During the same time, three approaches have been reported for the synthesis of mastigophorenes $\mathrm{A}$ and $\mathrm{B} 7$ and $\mathbf{8}$, and one of which has been extended to the synthesis of mastigophorenes $\mathrm{C}$ and D 9 and 10. ${ }^{8}$ Herein, we report the details of the formal total synthesis of $( \pm)$-herbertenediol and mastigophorenes A-D. ${ }^{9}$

\section{Results and Discussion}

For the formal total synthesis of herbertenediol and mastigophorenes cyclopentanone 22 was chosen as the target molecule, since its conversion to herbertenediol 5 and mastigophorenes A-D 7-10 has already been reported in the literature. ${ }^{7 \mathrm{~h}, 8 \mathrm{a}, \mathrm{d}}$ An intramolecular aldol condensation based strategy was contemplated for the construction of the cyclopentanone 22 as depicted in the retrosynthetic scheme 1 . Presence of two ortho oriented oxygen substituents prompted us to choose 2-methoxy-4-methylphenol $\mathbf{2 6}$, which could be readily obtained from vanillin $\mathbf{2 7}$, as the starting material. A Claisen rearrangement was considered as an ideal methodology for the introduction of a side chain at the C-6 position, which could be elaborated into cyclopentanone 22.
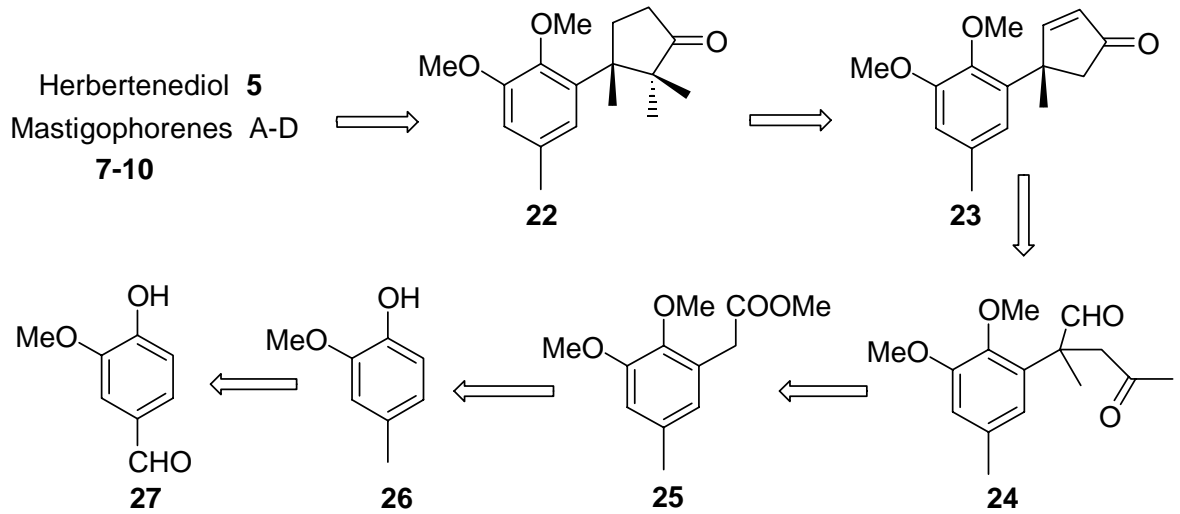

\section{Scheme 1}

The synthetic sequence is depicted in schemes 2 and 3. To begin with, vanillin 27 was converted into the phenol 26 via Clemmensen's reduction. ${ }^{10}$ Treatment of the phenol 26 with anhydrous potassium carbonate and allyl bromide in refluxing acetone generated the allyl aryl 
ether 28 in $92 \%$ yield, which on thermal activation at $180{ }^{\circ} \mathrm{C}$ furnished the ortho Claisen product 29 in $67 \%$ yield. The phenol 29 on etherification with dimethyl sulfate and 10\% aqueous sodium hydroxide generated the dimethoxy compound 30 in $87 \%$ yield. Ozonolytic cleavage of the allyl group in the compound $\mathbf{3 0}$ in methanol and methylene chloride followed by reductive workup with dimethyl sulfide gave the aldehyde 31 in $88 \%$ yield. Oxidation of the aldehyde 31 with 2.5 $\mathrm{M}$ Jones reagent in acetone at $0{ }^{\circ} \mathrm{C}$ furnished the acid ${ }^{8 \mathrm{a}} 32 \mathrm{in} 93 \%$ yield, which on esterification with methanol in the presence of sulfuric acid generated the ester 25 in $94 \%$ yield.<smiles>COc1cc(C(=O)c2ccc(Br)cc2)ccc1O</smiles>
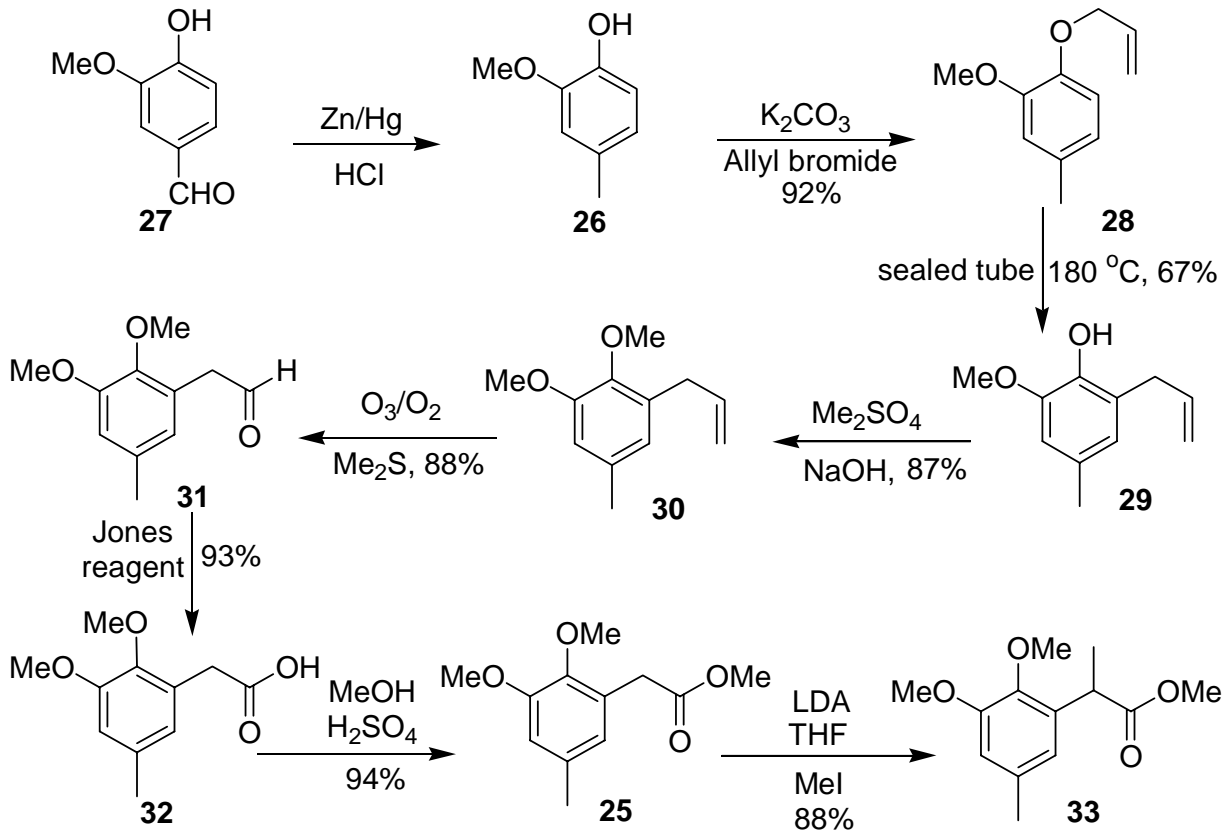<smiles>COC(=O)Cc1cc(C)cc(OC)c1OC</smiles><smiles>COC(=O)C(C)c1cc(C)cc(OC)c1OC</smiles>

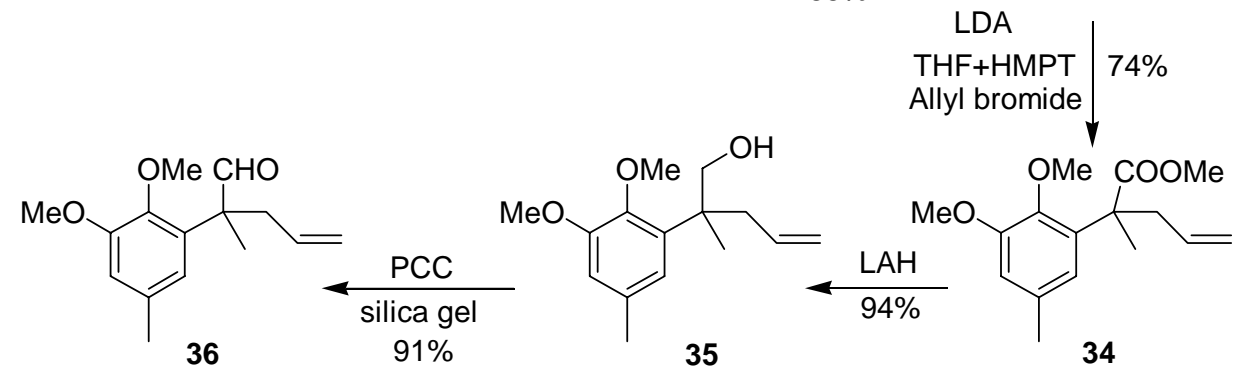

\section{Scheme 2}

For creating the first quaternary center, sequential alkylation of the ester $\mathbf{2 5}$ was explored. Thus, generation of the lithium enolate of the ester 25 with lithium diisopropylamide (LDA) in THF at $-70{ }^{\circ} \mathrm{C}$ followed by alkylation with methyl iodide furnished the ester 33 in $88 \%$ yield, whose structure rests secured from the spectral data. For the projected intramolecular aldol condensation for the generation of cyclopentenone 23, an allyl group was chosen as the acetone equivalent. Generation of the lithium enolate of the ester 33 with LDA in THF and HMPA at $70{ }^{\circ} \mathrm{C}$ followed by alkylation with allyl bromide generated the ester 34 in $74 \%$ yield. To avoid 
regiochemical problems at a later stage, the ester moiety in $\mathbf{3 4}$ was converted into an aldehyde. Consequently, reduction of the ester 34 using lithium aluminum hydride (LAH) in ether gave the primary alcohol 35 in 94\% yield, which on oxidation with pyridinium chlorochromate (PCC) and silica gel in methylene chloride furnished the aldehyde 36 in $91 \%$ yield.

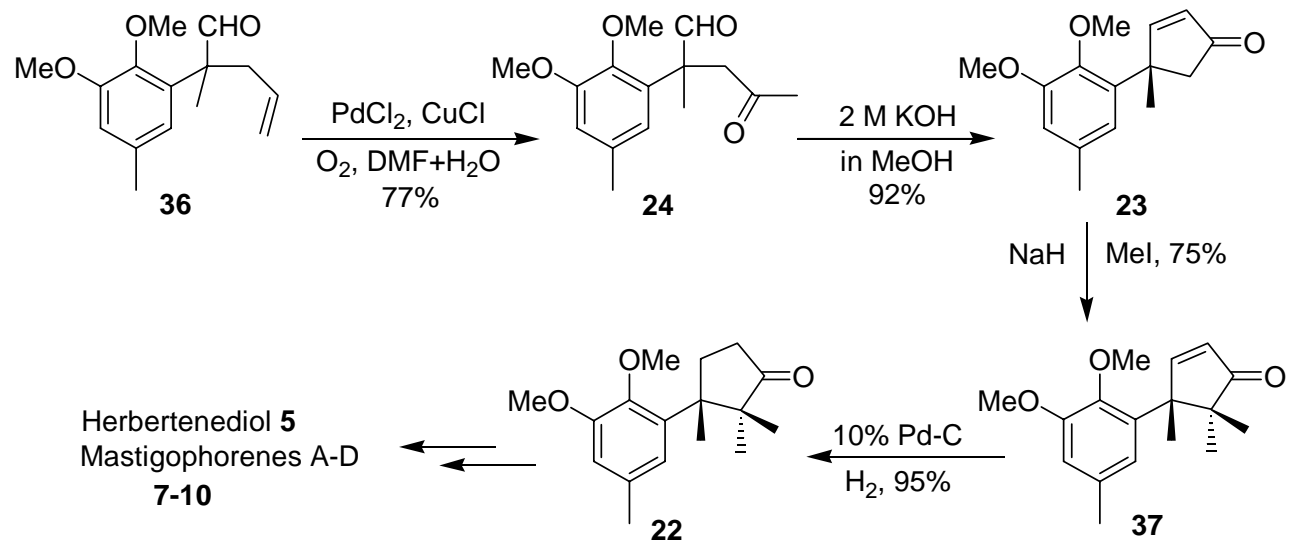

For the conversion of the terminal vinyl group in the pentenal 36 into an acetyl moiety, Wacker oxidation was chosen. ${ }^{11}$ Thus, treatment of the pentenal 36 with 0.2 equivalent of palladium chloride and 3 equivalents of cupric chloride in $N, N$-dimethylformamide (DMF) and water in oxygen atmosphere (balloon), produced the keto-aldehyde 24 in $77 \%$ yield. Intramolecular aldol condensation of the ketoaldehyde 24 with $2 M$ methanolic potassium hydroxide in THF at room temperature generated the cyclopentenone $\mathbf{2 3}$ in $92 \%$ yield. Presence of the molecular ion peak at $\mathrm{m} / \mathrm{z} 246\left(\mathrm{C}_{15} \mathrm{H}_{18} \mathrm{O}_{3}\right)$ in the mass spectrum and in the IR spectrum presence of an absorption band at $1715 \mathrm{~cm}^{-1}$ due to the cyclopentenone carbonyl group suggested the formation of the aldol product 23. In the ${ }^{1} \mathrm{H}$ NMR spectrum, presence of two typical doublets at $\delta 7.80$ and 6.15 due to the $\beta$ and $\alpha$ protons, respectively, of a cyclopentenone, and an $\mathrm{AB}$ quartet at 2.66 and $2.55 \mathrm{ppm}$ due to the methylene $\alpha$ to the ketone, established the structure of the cyclopentenone 23. The ${ }^{13} \mathrm{C}$ NMR spectrum with characteristic resonances, a quaternary carbon at $\delta 208.8$ due to the ketone, two methines at 170.7 and 130.7 due to the $\beta$ and $\alpha$ olefinic carbons, respectively, of a cyclopentenone and a methylene at $51.0 \mathrm{ppm}$ due to the $\mathrm{C}-5$ carbon, in addition to other resonances confirmed the structure of the cyclopentenone 23. Dialkylation of the cyclopentenone 23 using sodium hydride and methyl iodide in dry THF and DMF at room temperature, created the second quaternary centre and generated the enone 37 in $75 \%$ yield, whose structure was established from its spectral data, in particular the resonance at $0.65 \mathrm{ppm}$ in the ${ }^{1} \mathrm{H}$ NMR spectrum due to the C-5 methyl group, which is cis to the aromatic ring and experiencing the shielding effect of the aromatic $\pi$-cloud. Finally, hydrogenation of the enone 37 using $10 \%$ palladium over carbon as the catalyst at one atmospheric pressure (balloon) of hydrogen in ethanol, furnished the cyclopentanone 22 in $95 \%$ yield, which exhibited ${ }^{1} \mathrm{H}$ and ${ }^{13} \mathrm{C}$ NMR spectra identical to those of the sample obtained by Mukherjee and coworkers. ${ }^{7 \mathrm{~h}}$ Since the cyclopentanone 22 has already been converted ${ }^{7 \mathrm{~h}, 8 \mathrm{a}, \mathrm{d}}$ into herbertenediol 5 and mastigophorenes A-D 7-10, the present sequence constitutes a formal synthesis of these terpenoids. 


\section{Experimental Section}

General Procedures. IR spectra were recorded on Jasco FTIR 410 spectrophotometer. ${ }^{1} \mathrm{H}$ $(300 \mathrm{MHz})$ and ${ }^{13} \mathrm{C}(75 \mathrm{MHz})$ NMR spectra were recorded on JNM $\lambda-300$ spectrometer. The chemical shifts $(\delta \mathrm{ppm})$ and coupling constants $(\mathrm{Hz})$ are reported in the standard fashion with reference to either internal tetramethylsilane (for ${ }^{1} \mathrm{H}$ ) or the central line $\left(77.0 \mathrm{ppm}\right.$ ) of $\mathrm{CDCl}_{3}$ (for $\left.{ }^{13} \mathrm{C}\right)$. In the ${ }^{13} \mathrm{C}$ NMR spectra, the nature of the carbons $\left(\mathrm{C}, \mathrm{CH}, \mathrm{CH}_{2}\right.$ or $\left.\mathrm{CH}_{3}\right)$ was determined by recording DEPT-135 spectra, and are given in parentheses. Low-resolution mass spectra were recorded using Jeol JMS-DX 303 and Shimadzu QP-5050A GCMS instruments using direct inlet mode. Relative intensities are given in parentheses. High resolution mass spectra were recorded on a Micromass Q-TOF micro mass spectrometer using electron spray ionization mode. Ozonolysis experiments were carried out using Fischer 502 ozone generator. The oxygen flow was adjusted and calibrated to generate one mmole of ozone per four minutes. Hydrogenation reactions at one atmospheric pressure were carried out using a balloon filled with hydrogen. Acme's silica gel (100-200 mesh) was used for column chromatography. All small-scale dry reactions were carried out using standard syringe-septum technique. Low temperature reactions were conducted in a bath made of alcohol and liquid nitrogen.

2-Methoxy-4-methylphenyl allyl ether (28). To a magnetically stirred solution of the phenol 26 $(3.0 \mathrm{~g}, 21.7 \mathrm{mmol})$ in dry acetone $(10 \mathrm{ml})$ was added allyl bromide $(1.82 \mathrm{ml}, 21.7 \mathrm{mmol})$ and anhydrous $\mathrm{K}_{2} \mathrm{CO}_{3}(3.0 \mathrm{~g}, 21.7 \mathrm{mmol})$ and the reaction mixture was refluxed for $8 \mathrm{~h}$. It was then cooled, quenched with water $(10 \mathrm{ml})$ and extracted with ether $(3 \times 5 \mathrm{ml})$. The combined ether extract was washed with $2 \mathrm{~N}$ aqueous $\mathrm{NaOH}$ solution and brine, and dried $\left(\mathrm{Na}_{2} \mathrm{SO}_{4}\right)$. Evaporation of the solvent and purification of the residue over a silica gel column using ethyl acetate-hexane (1:10) as eluent furnished the allyl ether 28 (3.56 g, 92\%) as oil. ${ }^{12}$ IR (neat): $v_{\max } / \mathrm{cm}^{-1} 2932$, 2862, 1646, 1590, 1512, 1462, 1416, 1264, 1230, 1150, 1141, 1033, 996, $926\left(\mathrm{CH}=\mathrm{CH}_{2}\right), 845$, 801. ${ }^{1} \mathrm{H}$ NMR $\left(300 \mathrm{MHz}, \mathrm{CDCl}_{3}+\mathrm{CCl}_{4}\right): \delta 6.73(1 \mathrm{H}, \mathrm{d}, \mathrm{J}=8.1 \mathrm{~Hz}, \mathrm{H}-5), 6.66(1 \mathrm{H}, \mathrm{s}, \mathrm{H}-3), 6.62$ $(1 \mathrm{H}, \mathrm{d}, \mathrm{J}=8.1 \mathrm{~Hz}, \mathrm{H}-6), 6.05$ ( $1 \mathrm{H}, \mathrm{t}$ of dd, $\mathrm{J}=17.1,10.2$ and $5.4 \mathrm{~Hz}, \mathrm{H}-2$ '), 5.37 (1 H, dd, J=17.1 and $1.8 \mathrm{~Hz}$ ) and $5.24(1 \mathrm{H}, \mathrm{dd}, \mathrm{J}=10.2$ and $1.8 \mathrm{~Hz})\left[\mathrm{H}-3^{\prime}\right], 4.55\left(2 \mathrm{H}, \mathrm{d}, \mathrm{J}=5.4 \mathrm{~Hz}, \mathrm{H}-1^{\prime}\right), 3.84$ (3 $\left.\mathrm{H}, \mathrm{s}, \mathrm{OCH}_{3}\right), 2.29\left(3 \mathrm{H}, \mathrm{s}, \mathrm{ArCH}_{3}\right) .{ }^{13} \mathrm{C} \mathrm{NMR}\left(75 \mathrm{MHz}, \mathrm{CDCl}_{3}+\mathrm{CCl}_{4}\right): \delta 149.5(\mathrm{C})$ and $146.0(\mathrm{C})$ [C-1 and 2], $133.8\left(\mathrm{CH}, \mathrm{C}-2^{\prime}\right), 130.8(\mathrm{C}, \mathrm{C}-4), 120.9(\mathrm{CH}, \mathrm{C}-5), 117.6\left(\mathrm{CH}_{2}, \mathrm{C}-3{ }^{\prime}\right), 114.1(\mathrm{CH})$ and $113.0(\mathrm{CH})$ [C-3 and 6], $70.1\left(\mathrm{CH}_{2}, \mathrm{C}-1^{\prime}\right), 55.8\left(\mathrm{CH}_{3}, \mathrm{OCH}_{3}\right), 21.1\left(\mathrm{CH}_{3}, \mathrm{ArCH}_{3}\right)$.

2,3-Dimethoxy-5-methyl-1-allylbenzene (30). A solution of the allyl ether 28 (1.0 g, $5.62 \mathrm{mmol}$ ) was placed in a Carius tube and heated to $180{ }^{\circ} \mathrm{C}$ for $15 \mathrm{~h}$ under nitrogen atmosphere. The reaction mixture was then cooled and purified on a silica gel column using ethyl acetate-hexane $(1: 10)$ as eluent to furnish the phenol $29(670 \mathrm{mg}, 67 \%)$ as oil. ${ }^{12}$ IR (neat): $v_{\max } / \mathrm{cm}^{-1} 3536(\mathrm{OH}), 3075,3005,2914,1638,1608,1361,1294,1234,1212,1150,1076,996$, 943, $910\left(\mathrm{CH}=\mathrm{CH}_{2}\right), 834,790 .{ }^{1} \mathrm{H}$ NMR $\left(300 \mathrm{MHz}, \mathrm{CDCl}_{3}+\mathrm{CCl}_{4}\right): \delta 6.50(2 \mathrm{H}, \mathrm{s}, \mathrm{Ar}-\mathrm{H}), 5.95(1$ $\mathrm{H}, \mathrm{t}$ of dd, $\mathrm{J}=17.1,10.5$ and $\left.6.6 \mathrm{~Hz}, \mathrm{H}-2^{\prime}\right), 5.43(1 \mathrm{H}, \mathrm{s}, \mathrm{OH}), 5.06(1 \mathrm{H}, \mathrm{dd}, \mathrm{J}=17.1$ and $1.8 \mathrm{~Hz})$ and $5.02(1 \mathrm{H}, \mathrm{dd}, \mathrm{J}=10.5$ and $1.8 \mathrm{~Hz})\left[\mathrm{H}-3^{\prime}\right], 3.85\left(3 \mathrm{H}, \mathrm{s}, \mathrm{OCH}_{3}\right), 3.34\left(2 \mathrm{H}, \mathrm{d}, \mathrm{J}=6.6 \mathrm{~Hz}, \mathrm{H}-1^{\prime}\right)$, 
$2.25\left(3 \mathrm{H}, \mathrm{s}, \mathrm{ArCH}_{3}\right) .{ }^{13} \mathrm{C} \mathrm{NMR}\left(75 \mathrm{MHz}, \mathrm{CDCl}_{3}+\mathrm{CCl}_{4}\right): \delta 146.1(\mathrm{C}), 141.1(\mathrm{C}), 136.8(\mathrm{CH}, \mathrm{C}-$ 2'), 128.5 (C), 125.5 (C), 122.6 (CH, C-5), $115.4\left(\mathrm{CH}_{2}, \mathrm{C}-3\right.$ ') $109.5(\mathrm{CH}, \mathrm{C}-3), 55.9\left(\mathrm{CH}_{3}\right.$, $\left.\mathrm{OCH}_{3}\right), 33.9\left(\mathrm{CH}_{2}, \mathrm{C}-1\right.$ ' $), 21.1\left(\mathrm{CH}_{3}, \mathrm{ArCH}_{3}\right)$. Mass: $\left(\mathrm{C}_{11} \mathrm{H}_{14} \mathrm{O}_{2}\right) \mathrm{m} / \mathrm{z} 178\left(\mathrm{M}^{+}, 57 \%\right), 177$ (100), 163 (10), 145 (12), 135 (13), 115 (18), 105 (11), 91 (30). To a cold (10 $\left.{ }^{\circ} \mathrm{C}\right)$ magnetically stirred solution of the phenol $29(650 \mathrm{mg}, 3.65 \mathrm{mmol})$ in $10 \%$ aqueous $\mathrm{NaOH}$ solution $(5 \mathrm{ml})$ was added $\mathrm{Me}_{2} \mathrm{SO}_{4}(0.35 \mathrm{ml}, 3.65 \mathrm{mmol})$ drop wise and the reaction mixture was refluxed for $1 \mathrm{~h}$ at $70{ }^{\circ} \mathrm{C}$. It was then cooled and extracted with ether $(3 \times 3 \mathrm{ml})$. The ether extract was washed with brine and dried $\left(\mathrm{Na}_{2} \mathrm{SO}_{4}\right)$. Evaporation of the solvent and purification of the residue over a silica gel column using ethyl acetate-hexane (1:10) as eluent furnished the methyl ether 30 (610 mg, 87\%) as oil. IR (neat): $v_{\max } / \mathrm{cm}^{-1} 3076,2936,2830,1638,1589,1491,1463,1326,1289,1231,1184$, 1147, 1100, 1078, 1012, $911\left(\mathrm{CH}=\mathrm{CH}_{2}\right), 834 .{ }^{1} \mathrm{H} \mathrm{NMR}\left(300 \mathrm{MHz}, \mathrm{CDCl}_{3}+\mathrm{CCl}_{4}\right): \delta 6.54(1 \mathrm{H}, \mathrm{s})$ and $6.53(1 \mathrm{H}, \mathrm{s})[\mathrm{Ar}-\mathrm{H}], 5.90(1 \mathrm{H}, \mathrm{t}$ of dd, $\mathrm{J}=16.9,10.3$ and $6.6 \mathrm{~Hz}, \mathrm{H}-2$ ') $), 06$ (1 H, dd, J=16.9 and $1.5 \mathrm{~Hz})$ and $5.02(1 \mathrm{H}, \mathrm{dd}, \mathrm{J}=10.3$ and $1.5 \mathrm{~Hz})\left[\mathrm{H}-3^{\prime}\right], 3.82(3 \mathrm{H}, \mathrm{s})$ and $3.75(3 \mathrm{H}, \mathrm{s})[2 \mathrm{x}$ $\left.\mathrm{OCH}_{3}\right], 3.34\left(2 \mathrm{H}, \mathrm{d}, \mathrm{J}=6.6 \mathrm{~Hz}, \mathrm{H}-1\right.$ ') $2.27\left(3 \mathrm{H}, \mathrm{s}, \mathrm{ArCH}_{3}\right) .{ }^{13} \mathrm{C} \mathrm{NMR}\left(75 \mathrm{MHz}, \mathrm{CDCl}_{3}+\mathrm{CCl}_{4}\right): \delta$ 152.5 (C), 145.0 (C), 137.5 (CH, C-2'), 133.4 (C), 133.2 (C), $122.5(\mathrm{CH}, \mathrm{C}-6), 115.5\left(\mathrm{CH}_{2}, \mathrm{C}-\right.$ 3'), $111.5(\mathrm{CH}, \mathrm{C}-4), 60.6\left(\mathrm{CH}_{3}\right)$ and $55.7\left(\mathrm{CH}_{3}\right)$ [2 $\left.\mathrm{x} \mathrm{OCH}_{3}\right], 34.1\left(\mathrm{CH}_{2}, \mathrm{C}-1\right.$ '), $21.4\left(\mathrm{CH}_{3}\right.$, $\left.\mathrm{ArCH}_{3}\right)$. Mass: $\left(\mathrm{C}_{12} \mathrm{H}_{16} \mathrm{O}_{2}\right) \mathrm{m} / \mathrm{z} 192\left(\mathrm{M}^{+}, 18 \%\right), 191$ (55), 175 (100), 135 (37), 115 (24), 105 (41), 91 (71).

Methyl 2-(2,3-dimethoxy-5-methylphenyl)acetate (25). A pre-cooled $\left(-70{ }^{\circ} \mathrm{C}\right)$ mixture of ozone in oxygen was passed through a cold $\left(-70{ }^{\circ} \mathrm{C}\right)$ solution of the ether $30(500 \mathrm{mg}$, $2.60 \mathrm{mmol})$ and a catalytic amount of $\mathrm{NaHCO}_{3}$ in methanol $(1 \mathrm{ml})$ and $\mathrm{CH}_{2} \mathrm{Cl}_{2}(5 \mathrm{ml})$ for $12 \mathrm{~min}$. The reaction mixture was flushed off with oxygen, and $\mathrm{Me}_{2} \mathrm{~S}(1.3 \mathrm{ml})$ was added to the reaction mixture. It was then slowly warmed up to RT and magnetically stirred for $8 \mathrm{~h}$. Evaporation of the solvent and purification of the residue on a silica gel column using ethyl acetate-hexane $(1: 10)$ as eluent furnished the aldehyde 31 (444 mg, 88\%) as oil. IR (neat): $v_{\max } / \mathrm{cm}^{-1} 2939,2832,2724(\mathrm{H}-$ $\mathrm{C}=\mathrm{O}), 1723(\mathrm{C}=\mathrm{O}), 1590,1494,1463,1330,1287,1233,1148,1093,1007,838 .{ }^{1} \mathrm{H}$ NMR $(300$ $\left.\mathrm{MHz}, \mathrm{CDCl}_{3}+\mathrm{CCl}_{4}\right): \delta 9.66\left(1 \mathrm{H}, \mathrm{t}, \mathrm{J}=2.1 \mathrm{~Hz}, \mathrm{CH}_{2} \mathrm{CHO}\right), 6.64(1 \mathrm{H}, \mathrm{s})$ and $6.52(1 \mathrm{H}, \mathrm{s})$ [Ar-H], $3.85(3 \mathrm{H}, \mathrm{s})$ and $3.76(3 \mathrm{H}, \mathrm{s})\left[2 \mathrm{x} \mathrm{OCH}_{3}\right], 3.59(2 \mathrm{H}, \mathrm{d}, \mathrm{J}=2.1 \mathrm{~Hz}, \mathrm{H}-2), 2.29\left(3 \mathrm{H}, \mathrm{s}, \mathrm{ArCH}_{3}\right)$. ${ }^{13} \mathrm{C} \mathrm{NMR}\left(75 \mathrm{MHz}, \mathrm{CDCl}_{3}+\mathrm{CCl}_{4}\right): \delta 198.8(\mathrm{CH}, \mathrm{CHO}), 152.5(\mathrm{C}), 145.4(\mathrm{C}), 133.7(\mathrm{C}), 125.9$ (C), $123.2\left(\mathrm{CH}, \mathrm{C}-6\right.$ ') $113.0\left(\mathrm{CH}, \mathrm{C}-4\right.$ '), $60.4\left(\mathrm{CH}_{3}\right)$ and $55.6\left(\mathrm{CH}_{3}\right)\left[2 \mathrm{x} \mathrm{OCH}_{3}\right], 45.2\left(\mathrm{CH}_{2}, \mathrm{C}-\right.$ 2), $21.2\left(\mathrm{CH}_{3}, \mathrm{ArCH}_{3}\right)$. To a magnetically stirred solution of the aldehyde 31 (400 mg, $2.06 \mathrm{mmol})$ in acetone $(4 \mathrm{ml})$ was added a freshly prepared solution of Jones reagent $(2.5 \mathrm{M}$ solution, $5.0 \mathrm{ml}$ ) at $0{ }^{\circ} \mathrm{C}$. The reaction mixture was then stirred at RT for $2 \mathrm{~h}$. Excess of the reagent was decomposed by adding a few drops of propan-2-ol and the reaction mixture was extracted with ether $(3 \times 4 \mathrm{ml})$. The combined ether extract was washed with brine and dried $\left(\mathrm{Na}_{2} \mathrm{SO}_{4}\right)$. Evaporation of the solvent furnished the $\operatorname{acid}^{8 \mathrm{a}} 32(403 \mathrm{mg}, 93 \%)$. A solution of the acid 32 (400 mg, $1.90 \mathrm{mmol})$ in $\mathrm{MeOH}(5 \mathrm{ml})$ and a catalytic amount of conc. $\mathrm{H}_{2} \mathrm{SO}_{4}$ was refluxed for $6 \mathrm{~h}$. The reaction mixture was then concentrated under vacuo. The residue was taken in ether $(15 \mathrm{ml})$, washed with brine and dried $\left(\mathrm{Na}_{2} \mathrm{SO}_{4}\right)$. Evaporation of the solvent and purification of the residue over a silica gel column using ethyl acetate-hexane (1:10) as eluent 
furnished the methyl ester 25 (400 mg, 94\%) as oil. IR (neat): $v_{\max } / \mathrm{cm}^{-1} 2948,2835,1740$ $(\mathrm{OC}=\mathrm{O}), 1592,1496,1468,1434,1316,1236,1162,1090,1011,837,782,657 .{ }^{1} \mathrm{H}$ NMR $\left(300 \mathrm{MHz}, \mathrm{CDCl}_{3}+\mathrm{CCl}_{4}\right): \delta 6.61(1 \mathrm{H}, \mathrm{s})$ and $6.58(1 \mathrm{H}, \mathrm{s})[\mathrm{Ar}-\mathrm{H}], 3.83(3 \mathrm{H}, \mathrm{s})$ and $3.77(3 \mathrm{H}, \mathrm{s})$ [2 $\left.\mathrm{x} \mathrm{ArOCH}_{3}\right], 3.68\left(3 \mathrm{H}, \mathrm{s}, \mathrm{COOCH}_{3}\right), 3.58(2 \mathrm{H}, \mathrm{s}, \mathrm{H}-2), 2.28\left(3 \mathrm{H}, \mathrm{s}, \mathrm{ArCH}_{3}\right) .{ }^{13} \mathrm{C} \mathrm{NMR}$ (75 MHz, $\left.\mathrm{CDCl}_{3}+\mathrm{CCl}_{4}\right): \delta 171.9(\mathrm{C}, \mathrm{OC}=\mathrm{O}), 152.4(\mathrm{C}), 145.3(\mathrm{C}), 133.3(\mathrm{C}), 127.8(\mathrm{C}), 123.0$ (CH, C-6'), $112.7\left(\mathrm{CH}, \mathrm{C}-4{ }^{\prime}\right), 60.4\left(\mathrm{CH}_{3}\right), 55.6\left(\mathrm{CH}_{3}\right), 51.8\left(\mathrm{CH}_{3}\right), 35.5\left(\mathrm{CH}_{2}, \mathrm{C}-2\right), 21.3\left(\mathrm{CH}_{3}\right.$, $\mathrm{ArCH}_{3}$ ). Mass: m/z 224 (M+, 91\%), 209 (33), 177 (16), 165 (39), 150 (100), 149 (45), 105 (57), 91 (50). HRMS: $\mathrm{m} / \mathrm{z}$ Calcd. for $\mathrm{C}_{12} \mathrm{H}_{16} \mathrm{O}_{4} \mathrm{Na}(\mathrm{M}+\mathrm{Na}): 247.0946$. Found: 247.0952.

Methyl 2-(2,3-dimethoxy-5-methylphenyl)propionate (33). To a cold $\left(-70{ }^{\circ} \mathrm{C}\right)$, magnetically stirred solution of diisopropylamine $(0.96 \mathrm{ml}, 6.67 \mathrm{mmol})$ in anhydrous THF $(3 \mathrm{ml})$ was slowly added a solution of ${ }^{n} \mathrm{BuLi}(1.6 \mathrm{M}$ in hexane, $3.67 \mathrm{ml}, 5.87 \mathrm{mmol})$ and stirred for $10 \mathrm{~min}$. To LDA thus formed was added drop wise a solution of the ester $25(600 \mathrm{mg}, 2.67 \mathrm{mmol})$ in anhydrous THF $(3 \mathrm{ml})$ and stirred for $40 \mathrm{~min}$ at the same temperature. The enolate was then treated with MeI $(0.4 \mathrm{ml}, 6.67 \mathrm{mmol})$ and stirred for $3 \mathrm{~h}$ at RT. The reaction mixture was then diluted with water and extracted with ether $(3 \mathrm{x} 4 \mathrm{ml})$. The combined ether extract was washed sequentially with $3 \mathrm{~N}$ aqueous $\mathrm{HCl}$, saturated aqueous $\mathrm{NaHCO}_{3}$ solution and brine, and dried $\left(\mathrm{Na}_{2} \mathrm{SO}_{4}\right)$. Evaporation of the solvent and purification of the residue over a silica gel column using ethyl acetate-hexane (1:10) as eluent furnished the ester $33(560 \mathrm{mg}, 88 \%)$ as oil. IR (neat): $v_{\max } / \mathrm{cm}^{-1}$ 2940, 2833, 1739 (OC=O), 1589, 1492, 1462, 1332, 1297, 1231, 1201, 1058, 1008, 951, 906, 838, 781, 629. ${ }^{1} \mathrm{H}$ NMR (300 MHz, $\left.\mathrm{CDCl}_{3}+\mathrm{CCl}_{4}\right): \delta 6.57(2 \mathrm{H}, \mathrm{s}, \mathrm{Ar}-\mathrm{H}), 4.00(1 \mathrm{H}, \mathrm{q}, \mathrm{J}=6.6 \mathrm{~Hz}$, $\mathrm{H}-2), 3.80(3 \mathrm{H}, \mathrm{s})$ and $3.76(3 \mathrm{H}, \mathrm{s})\left[2 \mathrm{x} \mathrm{ArOCH}_{3}\right], 3.62\left(3 \mathrm{H}, \mathrm{s}, \mathrm{COOCH}_{3}\right), 2.26(3 \mathrm{H}, \mathrm{s}$, $\left.\mathrm{ArCH}_{3}\right), 1.38(3 \mathrm{H}, \mathrm{d}, \mathrm{J}=6.6 \mathrm{~Hz}, \mathrm{H}-3) .{ }^{13} \mathrm{C} \mathrm{NMR}\left(75 \mathrm{MHz}, \mathrm{CDCl}_{3}+\mathrm{CCl}_{4}\right): \delta 174.9(\mathrm{C}, \mathrm{OC}=\mathrm{O})$, $152.2(\mathrm{C}), 144.2(\mathrm{C}), 134.3(\mathrm{C}), 133.5(\mathrm{C}), 120.0(\mathrm{CH}, \mathrm{C}-6)$ ), $112.1\left(\mathrm{CH}, \mathrm{C}-4{ }^{\prime}\right), 60.5\left(\mathrm{CH}_{3}\right), 55.5$ $\left(\mathrm{CH}_{3}\right)$ and $51.7\left(\mathrm{CH}_{3}\right)\left[3 \times \mathrm{OCH}_{3}\right], 38.6(\mathrm{CH}, \mathrm{C}-2), 21.4\left(\mathrm{CH}_{3}, \mathrm{ArCH}_{3}\right), 18.1\left(\mathrm{CH}_{3}, \mathrm{C}-3\right)$. Mass: m/z 238 (M+1,60\%), 179 (77), 164 (100), 150 (47), 149 (28), 135 (13), 121 (31), 105 (12), 91 (26). HRMS: $\mathrm{m} / \mathrm{z}$ Calcd. for $\mathrm{C}_{13} \mathrm{H}_{18} \mathrm{O}_{4} \mathrm{Na}(\mathrm{M}+\mathrm{Na}): 261.1103$. Found: 261.1088 .

Methyl 2-methyl-2-(2,3-dimethoxy-5-methylphenyl)pent-4-enoate (34). Allylation of the ester $33(500 \mathrm{mg}, 2.10 \mathrm{mmol})$, employing the same procedure as above, using LDA [prepared from diisopropylamine $(0.9 \mathrm{ml}, 6.3 \mathrm{mmol})$ and ${ }^{n} \mathrm{BuLi}(1.6 \mathrm{M}$ in hexane, $3.6 \mathrm{ml}, 5.88 \mathrm{mmol})$ ] and allyl bromide $(0.6 \mathrm{ml}, 7.35 \mathrm{mmol})$ in THF ( $3 \mathrm{ml})$ and HMPA $(2 \mathrm{ml})$, furnished the ester $34(432 \mathrm{mg}$, $74 \%$ ) as oil. IR (neat): $v_{\max } / \mathrm{cm}^{-1} 3073,2978,2943,2834,1735$ (OC=O), 1640, 1587, 1480, 1463, 1450, 1323, 1279, 1234, 1144, 1066, 1008, $916\left(\mathrm{CH}=\mathrm{CH}_{2}\right), 835,781 .{ }^{1} \mathrm{H}$ NMR $(300 \mathrm{MHz}$, $\left.\mathrm{CDCl}_{3}+\mathrm{CCl}_{4}\right): \delta 6.62(1 \mathrm{H}, \mathrm{s})$ and $6.57(1 \mathrm{H}, \mathrm{s})[\mathrm{Ar}-\mathrm{H}], 5.48(1 \mathrm{H}, \mathrm{t}$ of dd, J=17.4, 9.6 and $7.5 \mathrm{~Hz}, \mathrm{H}-4), 5.00(1 \mathrm{H}, \mathrm{d}, \mathrm{J}=17.4 \mathrm{~Hz})$ and $4.96(1 \mathrm{H}, \mathrm{d}, \mathrm{J}=9.6 \mathrm{~Hz})[\mathrm{H}-5], 3.82(3 \mathrm{H}, \mathrm{s})$ and 3.74 $(3 \mathrm{H}, \mathrm{s})\left[2 \mathrm{x} \mathrm{ArOCH}_{3}\right], 3.65\left(3 \mathrm{H}, \mathrm{s}, \mathrm{COOCH}_{3}\right), 2.75-2.55(2 \mathrm{H}, \mathrm{m}, \mathrm{H}-3), 2.31\left(3 \mathrm{H}, \mathrm{s}, \mathrm{ArCH}_{3}\right)$, $1.42\left(3 \mathrm{H}, \mathrm{s}\right.$, tert- $\left.\mathrm{CH}_{3}\right) .{ }^{13} \mathrm{C} \mathrm{NMR}\left(75 \mathrm{MHz}, \mathrm{CDCl}_{3}+\mathrm{CCl}_{4}\right): \delta 176.4(\mathrm{C}, \mathrm{OC}=\mathrm{O}), 151.9(\mathrm{C}), 144.3$ (C), $136.8(\mathrm{C}), 134.2(\mathrm{CH}, \mathrm{C}-4), 131.9(\mathrm{C}), 118.9(\mathrm{CH}, \mathrm{C}-6), 117.8\left(\mathrm{CH}_{2}, \mathrm{C}-5\right), 112.4(\mathrm{CH}, \mathrm{C}-$ 4'), $59.7\left(\mathrm{CH}_{3}\right), 55.5\left(\mathrm{CH}_{3}\right), 51.4\left(\mathrm{CH}_{3}\right), 47.4(\mathrm{C}, \mathrm{C}-2), 42.3\left(\mathrm{CH}_{2}, \mathrm{C}-3\right), 23.4\left(\mathrm{CH}_{3}\right.$, tert- $\left.\mathrm{CH}_{3}\right)$, $21.6\left(\mathrm{CH}_{3}, \mathrm{ArCH}_{3}\right)$. Mass: m/z $278\left(\mathrm{M}^{+}, 31 \%\right), 219$ (64), 205 (66), 193 (26), 179 (35), 178 (35), 177 (100), 149 (36), 117 (29), 91 (60). HRMS: m/z Calcd. for $\mathrm{C}_{16} \mathrm{H}_{22} \mathrm{O}_{4} \mathrm{Na}(\mathrm{M}+\mathrm{Na})$ : 301.1416. 
Found: 301.1404.

2-(2,3-Dimethoxy-5-methylphenyl)-2-methylpent-4-enal (36). To a cold $\left(-20{ }^{\circ} \mathrm{C}\right)$ magnetically stirred solution of the ester $34(250 \mathrm{mg}, 0.90 \mathrm{mmol})$ in dry ether $(4 \mathrm{ml})$ was added LAH (17 mg, $0.45 \mathrm{mmol}$ ) in one portion. The reaction mixture was stirred at the same temperature for $2 \mathrm{~h}$ and allowed to warm to $0{ }^{\circ} \mathrm{C}$ over a period of $30 \mathrm{~min}$. Ethyl acetate $(2 \mathrm{ml})$ was carefully introduced to consume the excess reagent and the reaction was quenched with ice-cold water $(5 \mathrm{ml})$. The solution was filtered through a sintered funnel and the residue thoroughly washed with ether $(3 \mathrm{x}$ $5 \mathrm{ml})$. The ether layer was separated, washed with brine and dried $\left(\mathrm{Na}_{2} \mathrm{SO}_{4}\right)$. Evaporation of the solvent and purification of the residue over a silica gel column using ethyl acetate-hexane (1:5) as eluent furnished the primary alcohol $35(210 \mathrm{mg}, 94 \%)$ as oil. IR (neat): $v_{\max } / \mathrm{cm}^{-1} 3431(\mathrm{OH})$, 3072, 2950, 2936, 2832, 1638, 1581, 1464, 1417, 1321, 1279, 1232, 1187, 1145, 1062, 1036, 1007, $912\left(\mathrm{CH}=\mathrm{CH}_{2}\right), 835,779 .{ }^{1} \mathrm{H} \mathrm{NMR}\left(300 \mathrm{MHz}, \mathrm{CDCl}_{3}+\mathrm{CCl}_{4}\right): \delta 6.59(2 \mathrm{H}, \mathrm{s}, \mathrm{Ar}-\mathrm{H}), 5.52$ $(1 \mathrm{H}, \mathrm{t}$ of $\mathrm{dd}, \mathrm{J}=16.5,10.8$ and $6.6 \mathrm{~Hz}, \mathrm{H}-4), 4.97(1 \mathrm{H}, \mathrm{d}, \mathrm{J}=16.5 \mathrm{~Hz})$ and $4.91(1 \mathrm{H}, \mathrm{d}$, $\mathrm{J}=10.8 \mathrm{~Hz}$ ) [H-5], 3.92 and $3.58(2 \mathrm{H}, 2 \mathrm{x} \mathrm{d}, \mathrm{J}=10.8 \mathrm{~Hz}, \mathrm{H}-1), 3.82\left(6 \mathrm{H}, \mathrm{s}, 2 \mathrm{x} \mathrm{OCH}_{3}\right), 2.70(1 \mathrm{H}$, dd, $\mathrm{J}=13.5$ and $6.6 \mathrm{~Hz}), 2.33(1 \mathrm{H}, \mathrm{dd}, \mathrm{J}=13.5$ and $7.8 \mathrm{~Hz}), 2.27\left(3 \mathrm{H}, \mathrm{s}, \mathrm{ArCH}_{3}\right), 1.87(1 \mathrm{H}$, br s, $\mathrm{OH}), 1.31\left(3 \mathrm{H}\right.$, s, tert- $\left.\mathrm{CH}_{3}\right) .{ }^{13} \mathrm{C} \mathrm{NMR}\left(75 \mathrm{MHz}, \mathrm{CDCl}_{3}+\mathrm{CCl}_{4}\right): \delta 152.7(\mathrm{C}), 145.8(\mathrm{C}), 136.4$ (C), 135.3 (CH, C-4), 132.5 (C), $121.7\left(\mathrm{CH}, \mathrm{C}-6\right.$ '), $116.9\left(\mathrm{CH}_{2}, \mathrm{C}-5\right), 112.1(\mathrm{CH}, \mathrm{C}-4$ '), 70.3 $\left(\mathrm{CH}_{2}, \mathrm{CH}_{2} \mathrm{OH}\right), 60.3\left(\mathrm{CH}_{3}\right)$ and $55.5\left(\mathrm{CH}_{3}\right)\left[2 \times \mathrm{OCH}_{3}\right], 44.0(\mathrm{C}, \mathrm{C}-2), 42.0\left(\mathrm{CH}_{2}, \mathrm{C}-3\right), 23.7$ $\left(\mathrm{CH}_{3}\right.$, tert $\left.-\mathrm{CH}_{3}\right), 21.6\left(\mathrm{CH}_{3}, \mathrm{ArCH}_{3}\right)$. To a magnetically stirred suspension of PCC $(344 \mathrm{mg}$, $1.6 \mathrm{mmol})$ and silica gel $(344 \mathrm{mg})$ in dry $\mathrm{CH}_{2} \mathrm{Cl}_{2}(4 \mathrm{ml})$ was added a solution of the alcohol 35 (200 mg, $0.80 \mathrm{mmol}$ ) in $\mathrm{CH}_{2} \mathrm{Cl}_{2}(2 \mathrm{ml})$ and stirred vigorously for $1 \mathrm{~h}$ at $\mathrm{RT}$. The reaction mixture was then filtered through a small silica gel column, and the column eluted with more $\mathrm{CH}_{2} \mathrm{Cl}_{2}$. Evaporation of the solvent furnished the aldehyde $36(180 \mathrm{mg}, 91 \%)$ as oil. IR (neat): $v_{\max } / \mathrm{cm}^{-1}$ 3074, 2938, 2707 (H-C=O), $1725(\mathrm{C}=\mathrm{O}), 1586,1482,1464,1322,1236,1145,1055,1004,915$ $\left(\mathrm{CH}=\mathrm{CH}_{2}\right), 836 .{ }^{1} \mathrm{H} \mathrm{NMR}\left(300 \mathrm{MHz}, \mathrm{CDCl}_{3}+\mathrm{CCl}_{4}\right): \delta 9.55(1 \mathrm{H}, \mathrm{s}, \mathrm{CHO}), 6.64(1 \mathrm{H}, \mathrm{s})$ and 6.57 $(1 \mathrm{H}, \mathrm{s})[\mathrm{Ar}-\mathrm{H}], 5.52$ (1 H, t of dd, J=16.5, 11.1 and $7.5 \mathrm{~Hz}, \mathrm{H}-4), 4.99(1 \mathrm{H}, \mathrm{d}, \mathrm{J}=16.5 \mathrm{~Hz})$ and $4.97(1 \mathrm{H}, \mathrm{d}, \mathrm{J}=11.1 \mathrm{~Hz})[\mathrm{H}-5], 3.84(3 \mathrm{H}, \mathrm{s})$ and $3.72(3 \mathrm{H}, \mathrm{s})\left[2 \mathrm{x} \mathrm{OCH}_{3}\right], 2.58(2 \mathrm{H}, \mathrm{d}$, $\mathrm{J}=7.5 \mathrm{~Hz}, \mathrm{H}-3), 2.32\left(3 \mathrm{H}, \mathrm{s}, \mathrm{ArCH}_{3}\right), 1.28\left(3 \mathrm{H}\right.$, s, tert- $\left.\mathrm{CH}_{3}\right) .{ }^{13} \mathrm{C} \mathrm{NMR}\left(75 \mathrm{MHz}, \mathrm{CDCl}_{3}+\mathrm{CCl}_{4}\right)$ : $\delta 201.9$ (CH, CHO), 152.3 (C), 144.3 (C), 135.2 (C), 133.8 (CH, C-4), 133.0 (C), 120.0 (CH, C6'), $118.2\left(\mathrm{CH}_{2}, \mathrm{C}-5\right), 112.8\left(\mathrm{CH}, \mathrm{C}-4{ }^{\prime}\right), 60.3\left(\mathrm{CH}_{3}\right)$ and $55.6\left(\mathrm{CH}_{3}\right)$ [2 x $\left.\mathrm{OCH}_{3}\right], 51.4(\mathrm{C}, \mathrm{C}-2)$, $40.4\left(\mathrm{CH}_{2}, \mathrm{C}-3\right), 21.7\left(\mathrm{CH}_{3}\right), 20.5\left(\mathrm{CH}_{3}\right)$.

2-(2,3-Dimethoxy-5-methylphenyl)-2-methyl-4-oxovaleraldehyde (24). A suspension of palladium chloride (23 mg, $0.13 \mathrm{mmol})$ and cuprous chloride $(257 \mathrm{mg}, 1.92 \mathrm{mmol})$ in DMF $(2 \mathrm{ml})$ and water $(1 \mathrm{ml})$ was magnetically stirred in an oxygen atmosphere, created via evacuative displacement of air using an oxygen balloon, for $1 \mathrm{~h}$ at RT. A solution of the enal 36 (160 mg, $0.64 \mathrm{mmol}$ ) in DMF (2 ml) was added to the reaction mixture and stirred for $16 \mathrm{~h}$ at RT in the oxygen atmosphere. Then $3 \mathrm{~N}$ aq. $\mathrm{HCl}(5 \mathrm{ml})$ was added to the reaction mixture and extracted with ether $(3 \times 4 \mathrm{ml})$. The combined ether extract was washed with saturated aq. $\mathrm{NaHCO}_{3}$ solution and brine, and dried $\left(\mathrm{Na}_{2} \mathrm{SO}_{4}\right)$. Evaporation of the solvent and purification of the residue over a silica gel column using ethyl acetate-hexane (1:10) as eluent furnished the 
ketoaldehyde 24 (131 mg, 77\%) as oil. IR (neat): $v_{\max } / \mathrm{cm}^{-1} 2960,2939,2835,2721(\mathrm{H}-\mathrm{C}=\mathrm{O})$, $1716(\mathrm{C}=\mathrm{O}), 1587,1483,1464,1425,1360,1320,1280,1236,1186,1151,1061,1002,960$, 836, 775. ${ }^{1} \mathrm{H}$ NMR $\left(300 \mathrm{MHz}, \mathrm{CDCl}_{3}+\mathrm{CCl}_{4}\right): \delta 9.60(1 \mathrm{H}, \mathrm{s}, \mathrm{CHO}), 6.65(1 \mathrm{H}, \mathrm{s})$ and $6.60(1 \mathrm{H}$, s) $[\mathrm{Ar}-\mathrm{H}], 3.83(3 \mathrm{H}, \mathrm{s})$ and $3.75(3 \mathrm{H}, \mathrm{s})\left[2 \mathrm{x} \mathrm{OCH}_{3}\right], 3.03$ and $3.00(2 \mathrm{H}, \mathrm{AB} \mathrm{q}, \mathrm{J}=16.5 \mathrm{~Hz}, \mathrm{H}-$ 3), $2.32\left(3 \mathrm{H}, \mathrm{s}, \mathrm{ArCH}_{3}\right), 1.98\left(3 \mathrm{H}, \mathrm{s}, \mathrm{COCH}_{3}\right), 1.48\left(3 \mathrm{H}\right.$, s, tert $\left.-\mathrm{CH}_{3}\right) .{ }^{13} \mathrm{C} \mathrm{NMR}(75 \mathrm{MHz}$, $\left.\mathrm{CDCl}_{3}+\mathrm{CCl}_{4}\right): \delta 206.2(\mathrm{C}, \mathrm{C}=\mathrm{O}), 201.9(\mathrm{CH}, \mathrm{CHO}), 152.1(\mathrm{C}), 143.8(\mathrm{C}), 135.1(\mathrm{C}), 133.1(\mathrm{C})$, $119.7\left(\mathrm{CH}, \mathrm{C}-6\right.$ '), $112.9\left(\mathrm{CH}, \mathrm{C}-4\right.$ '), $60.2\left(\mathrm{CH}_{3}\right)$ and $55.6\left(\mathrm{CH}_{3}\right)$ [2 $\left.\mathrm{x} \mathrm{OCH}_{3}\right], 50.1(\mathrm{C}, \mathrm{C}-2), 49.6$ $\left(\mathrm{CH}_{2}, \mathrm{C}-3\right), 31.0\left(\mathrm{CH}_{3}, \mathrm{C}-5\right), 21.5\left(\mathrm{CH}_{3}\right), 20.7\left(\mathrm{CH}_{3}\right.$, tert $\left.-\mathrm{CH}_{3}\right)$.

4-Methyl-4-(2,3-dimethoxy-5-methylphenyl)cyclopent-2-enone (23). To a magnetically stirred solution of the ketoaldehyde $24(100 \mathrm{mg}, 0.38 \mathrm{mmol})$ in THF $(4 \mathrm{ml})$ was added $2 \mathrm{M} \mathrm{KOH}$ in $\mathrm{MeOH}(0.2 \mathrm{ml}, 0.38 \mathrm{mmol})$ and the reaction mixture was stirred for $5 \mathrm{~h}$. Solvent was evaporated under reduced pressure. It was then taken in ether $(10 \mathrm{ml})$ and washed with brine and dried $\left(\mathrm{Na}_{2} \mathrm{SO}_{4}\right)$. Evaporation of the solvent and purification of the residue over a silica gel column using ethyl acetate-hexane (1:10) as eluent furnished the cyclopentenone $23(86 \mathrm{mg}, 92 \%)$ as oil. IR (neat): $v_{\max } / \mathrm{cm}^{-1} 2934,1715(\mathrm{C}=\mathrm{O}), 1584,1483,1464,1419,1320,1237,1151,1055,1007$, 835, 803, 777. ${ }^{1} \mathrm{H}$ NMR (300 MHz, $\left.\mathrm{CDCl}_{3}+\mathrm{CCl}_{4}\right): \delta 7.80(1 \mathrm{H}, \mathrm{d}, \mathrm{J}=6.0 \mathrm{~Hz}, \mathrm{H}-3), 6.62(1 \mathrm{H}, \mathrm{s})$ and $6.53(1 \mathrm{H}, \mathrm{s})[\mathrm{Ar}-\mathrm{H}], 6.15(1 \mathrm{H}, \mathrm{d}, \mathrm{J}=6.0 \mathrm{~Hz}, \mathrm{H}-2), 3.83(3 \mathrm{H}, \mathrm{s})$ and $3.76(3 \mathrm{H}, \mathrm{s})[2 \mathrm{x}$ $\left.\mathrm{OCH}_{3}\right], 2.66$ and $2.55(2 \mathrm{H}, \mathrm{AB} \mathrm{q}, \mathrm{J}=18.3 \mathrm{~Hz}, \mathrm{H}-5), 2.28\left(3 \mathrm{H}, \mathrm{s}, \mathrm{ArCH}_{3}\right), 1.56\left(3 \mathrm{H}, \mathrm{s}\right.$, tert- $\left.\mathrm{CH}_{3}\right)$. ${ }^{13} \mathrm{C} \mathrm{NMR}\left(75 \mathrm{MHz}, \mathrm{CDCl}_{3}+\mathrm{CCl}_{4}\right): \delta 208.8(\mathrm{C}, \mathrm{C}=\mathrm{O}), 170.7(\mathrm{CH}, \mathrm{C}-3), 153.0(\mathrm{C}), 145.3(\mathrm{C})$, $138.1(\mathrm{C}), 132.6(\mathrm{C}), 130.7(\mathrm{CH}, \mathrm{C}-2), 119.2(\mathrm{CH}, \mathrm{C}-6), 112.6\left(\mathrm{CH}, \mathrm{C}-4{ }^{\prime}\right), 60.3\left(\mathrm{CH}_{3}\right)$ and 55.7 $\left(\mathrm{CH}_{3}\right)\left[2 \times \mathrm{OCH}_{3}\right], 51.0\left(\mathrm{CH}_{2}, \mathrm{C}-5\right), 47.3(\mathrm{C}, \mathrm{C}-4), 28.4\left(\mathrm{CH}_{3}\right.$, tert $\left.-\mathrm{CH}_{3}\right), 21.5\left(\mathrm{CH}_{3}, \mathrm{ArCH}_{3}\right)$. Mass: m/z 246 (M+, 100\%), 231 (38), 216 (29), 203 (26), 200 (20), 187 (32), 172 (20), 128 (19), 115 (32), 91 (29). HRMS: m/z Calcd. for $\mathrm{C}_{15} \mathrm{H}_{18} \mathrm{O}_{3} \mathrm{Na}(\mathrm{M}+\mathrm{Na}): 269.1154$. Found: 269.1155.

4-(2,3-Dimethoxy-5-methylphenyl)-4,5,5-trimethylcyclopent-2-enone (37). To a magnetically stirred suspension of $\mathrm{NaH}$ (22 $\mathrm{mg}, 60 \%$ dispersion in oil, $0.54 \mathrm{mmol}$, washed with dry hexanes) in THF (1 ml) was added a solution of the ketone $23(22 \mathrm{mg}, 0.09 \mathrm{mmol})$ in THF (2 ml) and DMF $(2 \mathrm{ml})$, and stirred for $40 \mathrm{~min}$ at RT. To the reaction mixture was added methyl iodide $(0.03 \mathrm{ml}, 0.54 \mathrm{mmol})$ and stirred for $12 \mathrm{~h}$ at RT. It was then quenched with water $(3 \mathrm{ml})$ and extracted with ether $(3 \times 3 \mathrm{ml})$. The combined ether extract was washed with brine and dried $\left(\mathrm{Na}_{2} \mathrm{SO}_{4}\right)$. Evaporation of the solvent and purification of the residue over a silica gel column using ethyl acetate-hexane (1:10) as eluent furnished the enone 37 (18 $\mathrm{mg}, 75 \%)$ as oil. IR (neat): $v_{\max } / \mathrm{cm}^{-1}$ 2969, 2936, 2871, $1707(\mathrm{C}=\mathrm{O}), 1586,1475,1463,1419,1319,1236,1148,1056$, 1006, 835. ${ }^{1} \mathrm{H}$ NMR $\left(300 \mathrm{MHz}, \mathrm{CDCl}_{3}+\mathrm{CCl}_{4}\right): \delta 7.89(1 \mathrm{H}, \mathrm{d}, \mathrm{J}=5.4 \mathrm{~Hz}, \mathrm{H}-3), 6.61(1 \mathrm{H}, \mathrm{s})$ and $6.45(1 \mathrm{H}, \mathrm{s})$ [Ar-H], $6.04(1 \mathrm{H}, \mathrm{d}, \mathrm{J}=5.4 \mathrm{~Hz}, \mathrm{H}-2), 3.84(3 \mathrm{H}, \mathrm{s})$ and $3.80(3 \mathrm{H}, \mathrm{s})\left[2 \mathrm{x} \mathrm{OCH}_{3}\right.$, $2.29\left(3 \mathrm{H}, \mathrm{s}, \mathrm{ArCH}_{3}\right), 1.47(3 \mathrm{H}, \mathrm{s}), 1.23(3 \mathrm{H}, \mathrm{s})$ and $0.65(3 \mathrm{H}, \mathrm{s})$ [3 x tert- $\left.\mathrm{CH}_{3}\right] .{ }^{13} \mathrm{C}$ NMR $(75$ $\left.\mathrm{MHz}, \mathrm{CDCl}_{3}+\mathrm{CCl}_{4}\right): \delta 213.6(\mathrm{C}=\mathrm{O}), 170.4(\mathrm{C}-3), 152.9(2 \mathrm{C}), 145.7,136.3,132.4,120.9,112.4$, 60.3, 55.7, 54.7, 50.9, 26.2, 21.6, 20.0 (2 C). Mass: m/z $274\left(\mathrm{M}^{+}, 42 \%\right), 259$ (100), 229 (12), 216 (7), 200 (8), 115 (13), 91 (14). HRMS: m/z Calcd. for $\mathrm{C}_{17} \mathrm{H}_{22} \mathrm{O}_{3} \mathrm{Na}(\mathrm{M}+\mathrm{Na})$ : 297.1467. Found: 297.1471 .

3-(2,3-Dimethoxy-5-methylphenyl)-2,2,3-trimethylcyclopentanone (22). To activated 10\% 
Pd-C (5 mg) was added a solution of the enone $37(18 \mathrm{mg}, 0.06 \mathrm{mmol})$ in ethanol $(2 \mathrm{ml})$. The reaction mixture was stirred for $1 \mathrm{~h}$ at $\mathrm{RT}$ in an atmosphere of hydrogen, created by evacuative replacement of air (balloon) and then the catalyst was filtered off. Evaporation of the solvent furnished the saturated ketone $22(17 \mathrm{mg}, 95 \%)$ as oil. IR (neat): $v_{\max } / \mathrm{cm}^{-1} 2965,2832,1736$ $(\mathrm{C}=\mathrm{O}), 1583,1463,1415,1376,1322,1270,1233,1187,1147,1085,1057,1006,961,835,781$, 749. ${ }^{1} \mathrm{H}$ NMR $\left(300 \mathrm{MHz}, \mathrm{CDCl}_{3}+\mathrm{CCl}_{4}\right): \delta 6.69(1 \mathrm{H}, \mathrm{s})$ and $6.59(1 \mathrm{H}, \mathrm{s})[\mathrm{Ar}-\mathrm{H}], 3.81(3 \mathrm{H}, \mathrm{s})$ and $3.76(3 \mathrm{H}, \mathrm{s})\left[2 \times \mathrm{OCH}_{3}\right], 2.65(1 \mathrm{H}, \mathrm{q}, \mathrm{J}=11.1 \mathrm{~Hz}), 2.50-2.30(2 \mathrm{H}, \mathrm{m}), 2.28(3 \mathrm{H}, \mathrm{s}, \mathrm{Ar}-$ $\left.\mathrm{CH}_{3}\right), 2.06(1 \mathrm{H}$, ddd, $\mathrm{J}=12.6,7.5$ and $3.3 \mathrm{~Hz}), 1.30(3 \mathrm{H}, \mathrm{s}), 1.22(3 \mathrm{H}, \mathrm{s})$ and $0.70(3 \mathrm{H}, \mathrm{s})[3 \mathrm{x}$ tert- $\left.\mathrm{CH}_{3}\right] .{ }^{13} \mathrm{C} \mathrm{NMR}\left(75 \mathrm{MHz}, \mathrm{CDCl}_{3}+\mathrm{CCl}_{4}\right): \delta 221.9(\mathrm{C}, \mathrm{C}=\mathrm{O}), 153.0(\mathrm{C}), 146.5(\mathrm{C}), 138.2$ (C), $132.0(\mathrm{C}), 120.7(\mathrm{CH}), 111.9(\mathrm{CH}), 60.1\left(\mathrm{CH}_{3}\right), 55.6\left(\mathrm{CH}_{3}\right), 53.5(\mathrm{C}), 49.6(\mathrm{C}), 34.0\left(\mathrm{CH}_{2}\right)$, $31.9\left(\mathrm{CH}_{2}\right), 24.5\left(\mathrm{CH}_{3}\right), 22.3\left(\mathrm{CH}_{3}\right), 21.7\left(\mathrm{CH}_{3}\right), 20.3\left(\mathrm{CH}_{3}\right)$. Mass: m/z $276\left(\mathrm{M}^{+}, 100 \%\right), 261$ (14), 243 (14), 227 (28), 206 (28), 205 (96), 191 (23), 177 (44), 175 (40), 174 (46), 173 (43), 159 (19), 131 (22), 115 (27), 105 (22), 91 (59). HRMS: m/z Calcd. for $\mathrm{C}_{17} \mathrm{H}_{24} \mathrm{O}_{3} \mathrm{Na}(\mathrm{M}+\mathrm{Na})$ : 299.1623. Found: 299.1623.

\section{Acknowledgements}

We thank Prof. D. Mukherjee for providing the copies of the NMR spectra of 22.

\section{References}

1. Irita, H.; Hashimoto, T.; Fukuyama, Y.; Asakawa, Y. Phytochemistry 2000, 55, 247.

2. Matsuo, A.; Yuki, S.; Nakayama, M. J. Chem. Soc., Chem. Commun. 1981, 864.

3. (a) Matsuo, A.; Yuki, S.; Nakayama, M.; Hayashi, S. Chem. Lett. 1982, 463. (b) Matsuo, A.; Nakayama, N.; Nakayama, M. Phytochemistry 1985, 24, 777. (c) Matsuo, A.; Yuki, S.; Nakayama, M. J. Chem. Soc., Perkin Trans. 1 1986, 701. (d) Asakawa, Y.; Matsuda, R..; Schofield, W. B; Gradstein, S. R. Phytochemistry 1982, 21, 2471.

4. Matsuo, A.; Yuki, S.; Nakayama, M. Chem. Lett. 1983, 1041.

5. (a) Fukuyama, Y.; Toyota, M.; Asakawa, Y. J. Chem. Soc., Chem. Commun. 1988, 1341. (b) Fukuyama, Y.; Asakawa, Y. J. Chem. Soc., Perkin Trans. 1, 1991, 2737. (c) Nagashima, F.; Nishioka, E.; Kameo, K.; Nakagawa, C.; Asakawa, Y. Phytochemistry 1991, 30, 215. (d) Asakawa, Y.; Lin, X.; Kondo, K.; Fukuyama, Y. Phytochemistry 1991, 30, 4019. (e) Toyota, M.; Koyama, H.; Asakawa, Y. Phytochemistry 1997, 46, 145.

6. (a) Kajimoto, T.; Yamashita, M.; Imamura, Y.; Takahashi, K.; Nohara, T.; Shibata, M. Chem. Lett. 1989, 527. (b) Buchanan, M. S.; Connolly, J. D.; Rycroft, D. S. Phytochemistry 1996, 43, 1245. (c) Hashimoto, T.; Irita, H.; Takaoka, S.; Tanaka, M.; Asakawa, Y. Tetrahedron 2000, 56, 3153. (d) Asakawa, Y. Phytochemistry 2001, 56, 297. (e) Feld, H.; Zapp, J.; Becker, H. Phytochemistry 2003, 64, 1335. 
7. (a) Eicher, T.; Servet, F.; Speicher, A. Synthesis 1996, 863. (b) Fukuyama, Y.; Kiriyama, Y.; Kodama, M. Tetrahedron Lett. 1996, 37, 1261. (c) Tori, M.; Miyake, T.; Hamaguchi, T.; Sono, M. Tetrahedron: Asymmetry 1997, 8, 2731. (d). Harrowven, D. C; Hannam, J. C. Tetrahedron Lett. 1998, 39, 9573. (e) Harrowven, D. C.; Hannam, J. C. Tetrahedron 1999, 55, 9333. (f) Ho, T. L.; Chang, M. H. J. Chem. Soc., Perkin Trans. 1 1999, 2479. (g) Abad, A.; Agullo, C.; Cunat, A. C.; Perni, R. H. J. Org. Chem. 1999, 64, 1741. (h) Pal, A.; Gupta, P. D.; Roy, A.; Mukherjee, D. Tetrahedron Lett. 1999, 40, 4733. (i) Abad, A.; Agullo, C.; Cunat, A. C.; Perni, R. H. Tetrahedron: Asymmetry 2000, 11, 1607. (j) Gupta, P. D.; Pal, A.; Roy, A.; Mukherjee, D. Tetrahedron Lett. 2000, 41, 7563. (k) Fukuyama, Y.; Matsumoto, K.; Tonoi, Y.; Yokoyama, R.; Takahashi, H.; Minami, H.; Okazaki, H.; Mitsumoto, Y. Tetrahedron 2001, 57, 7127. (1) Fukuyama, Y.; Yuasa, H.; Tonoi, Y.; Harada, K.; Wada, M.; Asakawa, Y.; Hashimoto, T. Tetrahedron 2001, 57, 9299. (m) Abad, A.; Agullo, C.; Cunat, A. C.; Jimenez, D.; Perni, R. H. Tetrahedron 2001, 57, 9727. (n) Nayek, A.; Ghosh, S. Tetrahedron Lett. 2002, 43, 1313. (o) Srikrishna, A.; Srinivasa Rao, M. Tetrahedron Lett. 2002, 43, 151. (p) Srikrishna, A.; Srinivasa Rao, M. Synlett 2002, 340. (q) Paul, T.; Pal, A.; Gupta, P. D.; Mukherjee, D. Tetrahedron Lett. 2003, 44, 737. (r) Srikrishna, A.; Satyanarayana, G. Tetrahedron Lett. 2003, 44, 1027. (s) Chavan, S. P.; Kharul, R. K.; Kale, R. R.; Khobragade, D. A Tetrahedron 2003, 59, 2737. (t) Zhao, X. Z.; Jia, Y. X.; Tu, Y. Q. J. Chem. Research (S) 2003, 54. (u) Nayek, A.; Drew, M. G. B.; Ghosh, S. Tetrahedron 2003, 59, 5175. (v) Kita, Y.; Futamura, J.; Ohba, Y.; Sawama, Y.; Ganesh, J. K.; Fujioka, H. Tetrahedron Lett. 2003, 44, 411. (w) Kita, Y.; Futamura, J.; Ohba, Y.; Sawama, Y.; Ganesh, J. K.; Fujioka, H. J. Org. Chem., 2003, 68, 5917. (x) Srikrishna, A.; Srinivasa Rao, M. Eur. J. Org. Chem. 2004, 499. (y) Srikrishna, A.; Babu, N. C.; Srinivasa Rao, M. Tetrahedron 2004, 60, 2125. (z) Ng, D.; Yang, Z.; Garcia-Garibay, M. A. Org. Lett. 2004, 6, 645. (aa) Boxall, R. J.; Ferris, L.; Grainger, R. S. Synlett 2004, 2379. (bb) Acherar, S.; Audran, G.; Fotiadu, F.; Monti, H. Eur. J. Org. Chem. 2004, 5092.

8. (a) Degnan, A. P.; Meyers, A. I. J. Am. Chem. Soc. 1999, 121, 2762. (b) Bringmann, G.; Pabst, T.; Rycroft, D. S.; Connolly, J. D. Tetrahedron Lett. 1999, 40, 483. (c) Bringmann, G.; Pabst, T.; Henschel, P.; Kraus, J.; Peters, K.; Peters, E. M.; Rycroft, D. S.;. Connolly, J. D. J. Am. Chem. Soc. 2000, 122, 9127. (d) Bringmann, G.; Pabst, T.; Henschel, P.; Michel, M. Tetrahedron 2001, 57, 1269.

9. Preliminary communication: Srikrishna, A.; Srinivasa Rao, M. Tetrahedron Lett. 2001, 42, 5781.

10. Schwarz, R.; Hering, H.; Shriner, R. L.; Furrow, C. L. Jr. Org. Synth. 1942, 1, 203.

11. (a) Tsuji, J.; Shimizu, I.; Yamamoto, K. Tetrahedron Lett. 1976, 2975.(b) Tsuji, J. Synthesis 1984, 369.

12. Singh, V.; Samanta, B. Synth. Commun. 1997, 27, 4235. 